\title{
Exploring the Exploits on the Instructional Conveyance of Robotics Course to the 4Cs of 21st Century Education
}

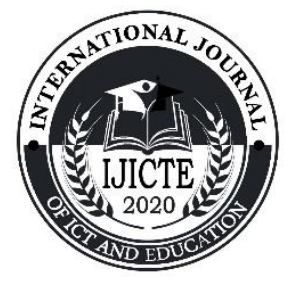

\author{
Lawrence G. Agapito
}

\begin{abstract}
This explanatory sequential mixed-method research proposes an investigation on the implementation of Robotics course at the Information and Communication Technology High School. Data were generated from relatable knowledge and experiences of the studentparticipants. The quantitative findings illustrated that it is highly evident amongst students to be able to articulate the standards of the competencies prescribed in the Robotics curriculum and instruction. A highly evident result in the adherence of Robotics to the framework of 21 st Century Learning was also registered and thus translates into the relevance and responsiveness of the course in the 21st Century Education frontline. Meanwhile, ten (10) student-participants explicitly described the contribution of Robotics in the pursuit of the 4Cs of education. The qualitative part validated the upshot of the quantitative section. Findings highlight the significance of Robotics in the pursuit of 21 st century skills that underscore enhanced ICT skills, focused life-long learning skills, increased knowledge creation, developed creativity skills, enriched critical thinking skills, improved collaborative skills, progressed communication skills, human challenges, and physical barriers. The offering of Robotics in ICTHS has made significant impact on the overall concepts and skills of the students in technology, thus making them life-long learners. However, adjustment in terms of instruction and acquisition of additional state-of-the-art robotics kits were found to be indispensable in the continuous progress of the program.
\end{abstract}

Keywords

robotics, 21 st century education, mixed-method research, $4 \mathrm{Cs}$

Suggested Citation: Agapito, L.G. (2021). Exploring the Exploits on the Instructional Conveyance of Robotics Course to the 4Cs of 21 st Century Education. International Journal of Information and Communication Technology and Education, Volume 2, Issue 1, pp. 1- 18.

About the author:

Teacher, Department of Education - Division of City of San Fernando, Pampanga 


\section{Introduction}

In order to better serve its stakeholders, the Department of Education undertook a major paradigm shift in order to respond positively to the challenges of the 21 st century. Due to this, an enhanced school planning and communication system should enable schools to better focus on maintaining balanced operations to become more responsive, efficient, and effective. Since the world shifted to industrial revolution 3.0, artificial intelligence (AI) and robotics increasingly became valuable tools that support learning activities in different learning areas. However, the challenge is to exploit technology within a pedagogically sound teaching and learning environment.

Robotics is one of the promising ways for developing highly demanded competencies such as computational and algorithmic thinking skills and programming. Moreover, it is believed to increase students' motivation towards a subject (García-Penalvo, Reimann, Tuul, Rees, \& Jormanainen, 2016). Furthermore, it contributes primarily to the generation of higher order thinking skills for learners. Hence, teachers and student's competence in technology should complement each other. The process of teaching and learning is a form of mutual understanding through communication by sharing the same specific knowledge and language system (Fernandes et al., 2018). Therefore, for teachers to develop digital competence, it is essential to find common ground with their students and be able to implement these skills into the educational process. Today's digital generation, a highly modified version of the original Bloom's Taxonomy is developed as a model for digital literacy skills (Phuapan et al., 2016). All the six categories form Anderson's Taxonomy in 2007 were adapted to the development of digital skills accordingly from lowest to the highest level and called Bloom's

Digital Taxonomy (Churches, 2007). Bloom's Digital Taxonomy explains activities with digital tools.

With the advancement of technology, it is complex to foresee what kinds of skills will be required by the time the learners of today finish schooling. Emerging technologies, such as 3D printing, machine learning, artificial intelligence and biotechnology are likely to transform some industries, and the World Economic Forum predicts that seven million jobs in the administrative, manufacturing and construction job families will disappear by 2020 (World Economic Forum, 2016). The International Labour Organization (2016) foresees that 
in 20 years robots will replace the jobs of 137 million people (56 per cent of the current employees) in five South-East Asia countries that includes Cambodia, Indonesia, Philippines, Thailand and Vietnam.

Handful of scholars have specified that students think that robotics courses help them develop hands-on skills, and more knowledge in science, technology, engineering, and mathematics (STEM) (Sullivan \& Heffernan, 2016). English (2016) developed an integrated STEM framework which links learning objectives and learning activities between different STEM disciplines. Doerschuk et al. (2016) also confirmed that through hands on robotics course, students increase their interest in STEM and career advancement. In general, students have evinced interest in robots, making robotics education popular in STEM areas (Rihtaršič, Avsec, \& Kocijancic, 2016).

Numerous facts were provided by researchers on the significant contributions of robotics course in the academic endeavors of the students. While DepEd has the aim to strengthen its current $\mathrm{K}$ to 12 basic education curriculum through diverse approaches on how to discover learning as a requisite for 21 st century education, robotics course offering can be an avenue to the realization of this goal.

As one of the channels of the foregoing educational paradigm, Robotics as a course is met with different modes of reception. Hence, the proponent proposes to introduce the gains and adherence of Robotics to the standards of 21st century education and examine its progression in a given time.

The K to 12 Basic Education Program of DepEd introduces the 21st Century skills which constitute lifelong learning. Hence, this study aims to assess the integration of Robotics into the curriculum of Information and Communication Technology High School. It is hoped that it will provide inputs for improvement; deliver feedbacks for possible implementation in other schools in the division and serve as basis for stakeholder support.

\section{Methodology}

\subsection{Research Design/Method}

The study used the mixed method of quantitative and qualitative types of research. The blending of the two types of research offers a thorough generation of knowledge 
extracted from the trend in the population along with an in-depth knowledge of the participants' perspective and experiences (Creswell \& Plano Clark, 2007).

Specifically, the explanatory sequential mixed method design (Creswell \& Plano Clark, 2011) was used in gathering data in teacher instruction and course content and adherence of Robotics Course to the 21st Century Skills (Critical thinking, Collaboration, Communication, Creativity and Use of Technology) in the Information and Communication Technology High School.

\subsection{Participants and Sampling}

For the quantitative part, the study used stratified random sampling consisted of 89 student-respondents from grade 7 to 10. According to Fraenkel, Wallen and Hyun (2012), stratified random sampling is "a process in which a certain subgroup, or strata, are selected for the sample in the same proportion as they exist in the population" (p. 95). On the other hand, purposive sampling is a non-probability sampling method is used when components selected for the sample are handpicked by the judgment of the researcher (Black, 2010).

While in the qualitative section, the study applied purposive sampling and 10 participants qualified based on the criteria set: a) he/she has taken robotics at ICTHS, S.Y 2016-2017; b) has experienced competing in the Regional and National robotics competitions; and c) has winnings of 1 st to 3rd places in the said levels of competition. Second collection of data through focus group discussion followed. Focus group relies upon words spoken by participants. A report based on focus groups features patterns formed by words, called themes or perspectives. Researchers must use specific methods to analyze patterns in spoken language (Creswell, 1998).

\subsection{Instrument}

Two (2) survey instruments were utilized. The first is a tool used by Berkeley Center for Teaching and Learning - course evaluation questions (2017). The evaluation tool consists of the following domains: Teacher instruction containing 18 items, Course Content (Organization, Clarity of Expectations/Directions, and Balance/Appropriateness) 8 items, Application \& Specific Skill Development 3 items, Theory/Content Knowledge 3 items and 10 items. The second instrument Adherence of Robotics Course in the 21st Century Skills (Critical thinking, Collaboration, Communication, Creativity and Use of Technology) with 
10 items was formed based from the 10 Essential Skills that all Good Roboticists by OwenHill (2016). These instruments were content validated by the officer-in-charge of research in the City Division, the Chief of the Curriculum and Implementation Division and a Ph.D. graduate research professor in one of the Universities in Pampanga, Philippines to ensure its overall clarity and usefulness in the study.

In the qualitative phase, the researcher used eight (8) open-ended questions through interview and focus group discussion. The open-ended questions allow participants to portray their experiences and perceptions in their own words and in their own contexts. This interview-guide was validated by experts in 1) qualitative research, 2) supervisor in charge of ICT, and 3) school head offering robotics course.

\subsection{Data Collection and Analysis}

The quantitative data gathered were treated with the use of weighted mean. While the qualitative data gathered through focus group discussion and interview were processed using coding and clustering of statements based on the transcript and extracted significant statements. The significant statements were coded using a process that allows organization of materials "into chunks or segments of texts" (Creswell et. al 2009 p 186).

The processing of qualitative data gathered ran from verbatim transcription of participants' responses or stories to the extraction of themes. Significant statements from the 14 groups in the focus group discussion and ten interviewees' transcripts were extracted. Identification was assigned to significant statements, "Ga, Gb, Gc...” for 'Group' and 'Sa' for Student" and numerals "1, 2, 3..." for the sequence significant statements from the participants. Codes using a process that allowed organizations of the materials "into chunks or segment of text" was later utilized to come up with the emerging themes (Creswell, et.al, 2009 p. 186).

Key point coding process was conducted by reading through the data and creating a storyline; categorizing data in codes; and using memos for clarification and interpretation. Codes are essence-capturing and essential elements of the research, that when grouped and organized according to analogous and consistent pattern, categories will be recognized and enable to establish a link based on the analysis procedure (Saldaña, 2015). 
Then, commonalities were grouped into concepts. At this stage, the researcher analyzed the codes to identify similarities and group them into categories based on their common properties. Concepts are abstract representations of events, objects, actions or interactions which allow the researcher to group similar information to better understand the data (Khandkar, 2015). From similar concepts, themes or categories were created. A theme creates a relevant aspect in connection with the research questions and denotes the level of patterned and marginally organizes and describes your data set in detail (Braun and Clarke, 2006). The researcher deciphered the emerging themes leading to the conclusions and recommendations. Conclusion drawing involves stepping back to consider what the analyzed data mean and to assess their implications for the questions at hand (Qualitative Analysis Handout, cited in Nicdao, 2015). Finally, the researcher sought the assistance of an expert, a Master Teacher in Filipino to analyze patterns in spoken language.

\section{Findings and Discussion}

\subsection{Quantitative results}

\section{Table 1}

Assessment of the Teacher Instruction as Regards Robotics Course Offering

\begin{tabular}{lcc}
\hline \multicolumn{1}{c}{ Indicators } & WM & VI \\
\hline 1. My teacher clearly presents the skills to be learned. & 3.36 & Highly Evident \\
2. My teacher effectively presents the tools (e.g. materials, skills, and techniques) & & \\
needed. & 3.56 & Highly Evident \\
3. My teacher effectively presents concepts and techniques. & 3.27 & Highly Evident \\
4. My teacher presents content in an organized manner. & 3.47 & Highly Evident \\
5. My teacher clearly articulates the standards of performance for the course. & 3.36 & Highly Evident \\
6. My teacher provides guidance for understanding course exercises. & 3.38 & Highly Evident \\
7. My teacher increases my understanding of course material. & 3.4 & Highly Evident \\
8. My teacher helps me define the goals and scope of the project. & 3.28 & Evident \\
9. My teacher helps me identify resources I needed to carry out the project. & 3.49 & Highly Evident \\
10. My teacher is helpful when I have difficulty performing activities. & 3.44 & Highly Evident \\
11. My teacher is readily available during the class. & 3.45 & Highly Evident \\
12. My teacher provides clear constructive feedback. & 3.35 & Highly Evident \\
13. My teacher clearly articulates the standards of performance. & 3.4 & Highly Evident \\
14. My teacher engages the class in productive discussions. & 3.12 & Evident \\
15. My teacher facilitates the discussion well. & 3.31 & Highly Evident \\
16. My teacher encourages critical engagement with the material. & 3.3 & Highly Evident \\
17. My teacher encourages student questions and participation. & 3.4 & Highly Evident \\
18. My teacher clearly presents the skills to be learned. & 3.12 & Evident \\
\hline
\end{tabular}

\begin{tabular}{lll}
\hline Over-all & $\mathbf{3 . 3 6}$ Highly Evident
\end{tabular}

Legend: $3.26-4.00$ Highly evident; $2.51-3.25$ Evident; 1.76 - 2.50 Moderately evident; $1.00-1.75$ Negligible 
With an obtained over-all mean of 3.36. In general, the delivery of instruction by the teacher in teaching robotics is perceived to be effective and compatible with the standards of 21 st Century competencies. Of the 18 items in teacher instruction, items 14 and 18 were the indicators that did not register the highest gain. This suggests a need for more efforts to be exerted during class discussions to make learning more productive and achieve its fullest gain.

Table 1 shows a result of highly evident which indicates that content delivery is effective. In preparing students in the field of Science and Technology initiatives in instruction should take place to be able to adopt to change.; Kazmierczak \& James, 2005 stated that, NXT Robotics class can be achieved through careful planning of instruction that is aligned and facilitated by teachers who have acquired the skills through staff development concentrating 28 on knowledge, flexibility, and the interests of students at diverse learning levels. While in the 21 st century learning framework, it is not enough that students just learn basic skills and curriculum, but they should explore opportunities to expand their learning and gain expertise (Literacy, 2012).

Table 2

Assessment of the Course Content as Regards Robotics Course Offering

\begin{tabular}{|c|c|c|}
\hline Indicator & WM & Verbal \\
\hline 19. The course lesson is appropriate for the level of the class. & 3.64 & Highly Evident \\
\hline 20. The course lesson is organized in a way that helps me learn. & 3.52 & Highly Evident \\
\hline 21. The course lesson provides a combination of explanation and practice. & 3.54 & Highly Evident \\
\hline 22. The course lesson is effectively organized. & 3.45 & Highly Evident \\
\hline 23. The course lesson assignments and lectures usefully complement each other. & 3.27 & Highly Evident \\
\hline 24. The course lesson instructions (including, manuals, handouts, etc.) are clear. & 3.39 & Highly Evident \\
\hline 25. The course lesson work helps me understand concepts more clearly. & 3.43 & Highly Evident \\
\hline 26. The lab complements my understanding of the lectures. & 3.54 & Highly Evident \\
\hline \multicolumn{3}{|l|}{ Application \& Specific Skill Development } \\
\hline 27. The course lesson develops my ability to interact with diverse groups of people. & 3.53 & Highly Evident \\
\hline 28. The course lesson provides guidance on how to become a competent professional. & 3.29 & Highly Evident \\
\hline 29. The course lesson develops my ability to present ideas/concepts. & 3.55 & Highly Evident \\
\hline \multicolumn{3}{|l|}{ Content Knowledge } \\
\hline 30. The course lesson allows me to synthesize fundamental knowledge and skills. & 3.47 & Highly Evident \\
\hline 31. The course lesson improves my problem-solving skills. & 3.45 & Highly Evident \\
\hline 32. The course lesson develops my ability to think critically about the subject. & 3.63 & Highly Evident \\
\hline Over-all & 3.48 & Highly Evident \\
\hline Legend: 3.26 - 4.00 Highly evident; 2.51 - 3.25 Evident; 1.76 - 2.50 Moderately evident; 1.00 - & $.75 \mathrm{Neg}$ & igible \\
\hline
\end{tabular}


Table 2 presents the course content as translated into its organization, clarity of expectations/directions, and balance/appropriateness. Based on data shown, all items registered excellent. At 3.48, overall mean indicates that the application and development of specific skills and content knowledge are excellent in these items.

Table 3

Adherence of Robotics Course on the 4Cs of 21st Century Skills

\begin{tabular}{|c|c|c|}
\hline Indicators & WM & VI \\
\hline $\begin{array}{l}\text { 1. It develops systems thinking through mechanics, electronics, electrics, } \\
\text { programming, sensing and even psychology and cognition. }\end{array}$ & 3.54 & Highly Evident \\
\hline $\begin{array}{l}\text { 2. It develops programming mindset that involves any stage of } \\
\text { programming abstraction. }\end{array}$ & 3.44 & Highly Evident \\
\hline $\begin{array}{l}\text { 3. It develops active learning that is essential in comprehension, grasps the } \\
\text { learning strategies that work personally and helps to learn new things } \\
\text { quickly and easily when the need arises. }\end{array}$ & 3.45 & Highly Evident \\
\hline $\begin{array}{l}\text { 4. It cultivates mathematical skills because at a basic level, robotics relies } \\
\text { on being able to understand and manipulate abstract concepts, often } \\
\text { representing those concepts as functions or equations. }\end{array}$ & 3.13 & Evident \\
\hline $\begin{array}{l}\text { 5. It advances science or other applied mathematics thought applying the } \\
\text { concepts to the real world. }\end{array}$ & 3.29 & Highly Evident \\
\hline $\begin{array}{l}\text { 6. It develops decision making skills through analytical thinking that } \\
\text { allows' analyzing the problem from various angles. }\end{array}$ & 3.45 & Highly Evident \\
\hline $\begin{array}{l}\text { 7. It cultivates critical thinking skills through the use of logic and reasoning } \\
\text { to balance the strengths and weaknesses of each solution. }\end{array}$ & 3.45 & Highly Evident \\
\hline $\begin{array}{l}\text { 8. It develops effective communication through often explaining concepts } \\
\text { in speaking and writing. }\end{array}$ & 3.26 & Highly Evident \\
\hline $\begin{array}{l}\text { 9. It develops proficiency in technology design through designing things } \\
\text { and able to figure out why something isn't working properly and come up } \\
\text { with possible solutions or repair. }\end{array}$ & 3.6 & Highly Evident \\
\hline $\begin{array}{l}\text { 10. It develops solving complex problem through fixing problems before } \\
\text { they even arise and troubleshooting them if they do arise. }\end{array}$ & 3.38 & Highly Evident \\
\hline
\end{tabular}

Legend: 3.26 - 4.00 Highly evident; $2.51-3.25$ Evident; 1.76 - 2.50 Moderately evident; $1.00-1.75$ Negligible

Table 3 shows the Adherence of Robotics Course on the 4Cs of 21st Century Skills which includes critical thinking, collaboration, communication, and creativity and use of technology. It reveals that nine (9) out of ten items registered excellent. However, results for cultivating mathematical skills through robotics indicate potential to improve to the highest gain. With an over-all mean of 3.40, the robotics course offered at ICTHS adheres to the 21st century skills. 
Meanwhile, a result of highly evident shows that the $21^{\text {st }}$ century skills were developed in the students. According to the 21 st century framework, in order to be prepared for complex lives and work environments, the 21 st century students must learn essential skill sets that will help them become "engaged thinkers and ethical citizens with an entrepreneurial spirit" (Literacy, 2012; Alberta education, 2012). These skills are: creativity and innovation, critical thinking and problem solving, social responsibility and cultural, global and environmental awareness, communication, digital literacy, collaboration and leadership, lifelong learning and self-direction and personal management (Literacy, 2012; Alberta education, 2012).

Robotics, as a new technology, has attracted educators' attention and has begun to be used as an educational tool. Therefore, there is a need to deeply examine the effects of robotics on students' personal skills and abilities. Some studies demonstrated the use of robotics, as a new technology, can improve students' personal skills, such as self-confidence, problem solving, communication, acquire and evaluate information, creativity, decision making, and team work (Khanlari, 2013, Hussain et al., 2006; Nugent et al., 2010; Arlegui et al., 2008; Demetriou, 2011). As stated by Davis et al. (2008) researchers and educators have demonstrated that digital technology dramatically affects and changes students' personalities and identities, increases intellectual capacities, and participates "in the transformation of minds, that is experiences of consciousness".

\subsection{Qualitative results}

\subsubsection{Emergence of Themes/Categories}

a. Pinalawak na Konseptong pang-ICT (Expanded ICT concepts) - the studentparticipants gave significant thoughts on how robotics expanded their concepts of ICT through the introduction of modern technology theories.

"Nang dahil ditto mas nagging adavnace ang aming kaalaman tiungkol sa kursong robotics at iba pang IT courses." - Ga6

"Mas napapalawak ang aming kaalaman sa kusong ito sa pamamagitan ng paggawang mga bagay na "Advance” at may kinalaman sa kursong ito. " - Gf3 
"Ito ay napakalawak sa aking pag iisp ng lubusan at ditto ko rin natutunan ang iba't ibang bagay tungkol sa teknolohiya." - Gh3

"Napalawak ng kursong robotics ang aking kaisipan dahil marami akong natutunan tunkol sa iba't ibang klase ng robot." - Gi2

b. Nalinang na Kasanayang pang-ICT (Enhanced ICT skills) - significant insights were given by the student-participants as to how their skills was enhanced through programing and other related ICT skills.

"Natuto kaming mangalikot ng mga ibang klase pa ng teknolohiya at lumawak pa ang kaalaman naming dito. - Gc3

"It helped us construct robots by ourselves as well as program them." Gc7

"Nagkaroon ako ng kaalaman sa teknolohiya, at natuto akong gumawa ng robot na akala kong mahirap." - Gg5

"Sa pamamagitan ng mga bagong mga kagamitan at impormasyon na naituro sa amin upang maintindihan ng mabuti ang mga kursong robotics." - Gi5

c. Nakatuon sa panghabang-buhay na Pagkatuto (Focused life-long learning skills) The student-participants also shared their meaningful experiences on the usefulness of robotics in their everyday living.

"Mas napaunlad at napalawak ko pa ang kaalaman tungkol sa teknolohiya at ang aplikasyon nito sa totoong buhay." - Gn6

"Natutunan naming ang fundamentals ng mga makabagong teknolohiya sa panahong ito lalo na't puno ng aplikasyon ng mga technology related na Gawain." Gb1

"Nalaman kong marami pa palang mga bagay ang hindi ko alam at nahahasa ang abilidad ko sa paggawang robot." - Gb4

"Nagagamit kopo ang natutunan ko sa robotics tuwing nasisira ang laruan ng aking kapatid." - Gd6

d. Pinag-ibayong kaalaman sa Paglikha (Increased knowledge creation) - while DepEd's advocacy in the implementation of the $\mathrm{K}$ to 12 , the student-participants realized robotics as a subject that drives them to knowledge creation. 
“Nakapagdudulot ng curiosity ang robotics para amin at ang robotics din ay nakapagdudulot sa atin upang mag try ng kung anu-ano, dahil sa kursong robotics, anything is possible." - Gb6

Natuto kaming mangalikot ng mga ibang klase pa ng teknolohiya at lumawak pa ang kaalaman naming dito. - Gc3

"Robotics course helped me learn the basic of how different robotic parts work and how they work together. I have also increased my knowledge on very basic programming and assembly of parts to create an ideal output suited for its purpose." - Gn5

"Natuto po akong mga programming at mas napabuti ko ang aking abilidad sa pag-aaanalisa." - Gm4

e. Nalinang ang Kasanayang Pagkamalikhain (Developed creativity skills) Creativity is one of the $21^{\text {st }}$ century skills. Consonant with this, student-participants shared their experiences as to how their creative skills were developed and helped them in their ICT endeavors.

"Robotics improve the creativity of person by making robots. - Ge5

"Sa pagkakataong nabibigyan kami ng oras upang gumawang aming sariling disenyo $n g$ robot ay nailalabas naming an gaming pagiging malikhain. - Sal

"Nagkaroon kami ng ideya kung paano ba mag-program ang isang konsepto ng robot at natutunan din naming ang basic modeling of simple robot." - G12a

“Dahil sa kursong robotics ay nakapalawak ang aking imahinasyon." $G d 8$

f. Pinag-igting na Kasanayan sa Kritikal na Pag-iisip (Enriched critical thinking skills) - On the enrichment of their critical thinking skills, they stressed how they were challenged by the different activities of the course. The following accounts illustrate the significance of the robotics in the $21^{\text {st }}$ century education.

"Patuloy na umuunlad ang kritikal na pag iisip sapagkat ikaw ang nagiisip kung papaano mo papagalawin ang iyong robot na ginawa." $\mathrm{Sa} 2$ 
Tuwing nagpoprogram sapagkat nangangailangan ito ng lohikal ta kritikal nap ag iisip upang magawa ito ng maayos." - Sf2

"Exploring these solutions will benefit the student's critical and analytical." - Gn5

"It helped us to increase our level in critical thinking and in solving / fixing problems through the given / certain instruction." - Gn7

g. Pinagbuting kasanayan sa kolaboratibong Gawain (Improved collaborative skills)

- The collaborative skills defined by the student-participants were impressive in majority because it communicates positive feedbacks and impact in their learning. Here are some of the excerpts of the student-participants.

"Mas napappalawak ko ang aking isipan kapag sa group work." - Sa4

"Teamwork, kung po paano mabububo/mapoprogram ang robot ng maayos at may kaisahan." - Sb4

"Kapag nakikipagtulungan sa iba pang miyembro upang mabilis na matapos ang isang robot," - Sc4

"Sa pakikipagtulungan sa iba pang mga miyembro para mabilis ang programming at assembly." - Se4

h. Epektibong Kasanayan sa Pakikipagtalastasan (Progressed communication skills) - the student-participants outlined the importance of communication skills as fundamentals of $21^{\text {st }}$ century education. To substantiate the findings are the statements of the student-participants.

"Napabubuti ang iyong pakikipagtalastasan sa pagkakataong nagbibigay ka ng ideya sa robot na ginawa." - Sa3

"Kapag ipinaliwanag ang mismong robot at "purpose" o mga kayang gawin ng robot." - Sb3

"Sa pagpapaliwanag sa iba kung ano ang purpose ng robot,para saan ito at kung paano ito buuin." - Sd4

"Dahil sa robotics matuto ka makisalamuha at makipag usap sa inyong mga kagrupo." - Sh3 
i. Pagsubok na Pangkatauhan (Human Challenges) - The student-participants shared their views on how instruction in robotics can still progress in other ways. The following accounts illustrate the student-participants' observations and suggestions.

"Mas palawigi pa ang mga konsepto at kaalaman sa kursong robotics, mas pag-aralan pa ng mabuti ang kursong ito at magdiskubre pa ng mga bagay kung paano mas magiging maganda at ma improve pa ang konsepto ng robot at ng isang robot.” - Gj10

"Smaller group during the assembly of the robot." - Gc13

"More activities helping the students whom were having difficulty in this subject." - Gc14

"Kailangan pang magturo ng madami hindi lamang paggamit ng Ingles kundi pati na rin tagalog para mas maintindihan.” - Gh7

"Maglaan san ang mas mahabang oras para ditto." - Gm13

j. Pisikal na Hadlang (Physical Barriers) - at the onset of introducing $21^{\text {st }}$ century programs, the student-participants stated the existing barriers in the continuous progress of the robotics program and one of them is physical barrier. Stated below are some of the accounts of the student-participants.

"It's already perfect, but If I were to choose something to improve it would be the robots that we build." - Ga8

"Kung napopponduhan ito ng pamahalaan upang mas maging bukas ang kaisipan ng mga magaaral at lumawak ang kanilang kaalaman." - Ga14

"Robotic kits for at least person per kit." - Gd11

"Bumili ng mas bago at updated na kit at magbigay ng mas maraming hand on activity." - Gk8

"I think that accept for having complete materials, they should also providelestablish the advancement of technologies.” - Gn14

"Hire more professional teachers. Although we have one, but they can hire more teachers with higher / has undergo training and expert studies about the said course and subject." - Gn15 


\subsubsection{Diagrammatical Emergence of Categories}

Natutong palawakin ang kaalaman sa teknolohiya (learned to broaden technological perspectives)

Napayaman ang kaalaman na dulot ng robotics (enriched knowledge acquired from robotics)

Natuto ng pananaliksik dahil sa mga makabagong kagamitan (learned to research using hi-technology materials)

\section{Pinalawak na Konseptong pang-ICT \\ (Expanded ICT concepts)}

Natuto ng siyentipikong paraan ng programing sa robot (Learned scientific method of programming a robot)

Nagkaroon ng karanasan sa pag-program ng robot (acquired experience in robot programming)

Naipakilala ang makabagong teknolohiya sa pamamagitan ng robotics (cutting edge technology is introduced through robotics)

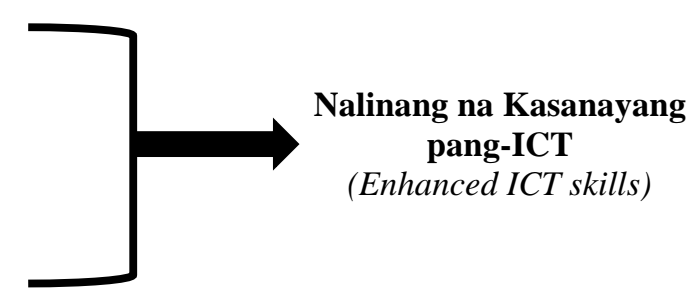

Nagamit ang kaalaman ng robotics sa ibang gawaing teknolohiya (applied robotics concepts in other technology-oriented tasks)

Nakatulong ang robotics para makatugon sa pagbabago ng panahon (robotics served to help learners cope with the changing times) Nakatulong ang mga kaalaman sa pang-araw-araw na buhay (robotics concepts helped in everyday living)

Natutong bumuo ng konsepto (Learned to construct concepts)

Natutong maghanap ng paraan para masolusyunan ang problema (helped to look for ways to solve problems)

Pinag-ibayong kaalaman sa Paglikha

(Increased knowledge creation)

Naipamamalas ang malikhaing kaisipan sa pamamagitan ng performance task (creativity is demonstrated through performance tasks)

Lumalabas ang pagkamalikhain kapag gumagawa ng robot (Creativity is channeled off when making a robot)

Nalilinang nang lubos ang pagkamalikhain (Creativity is optimized)

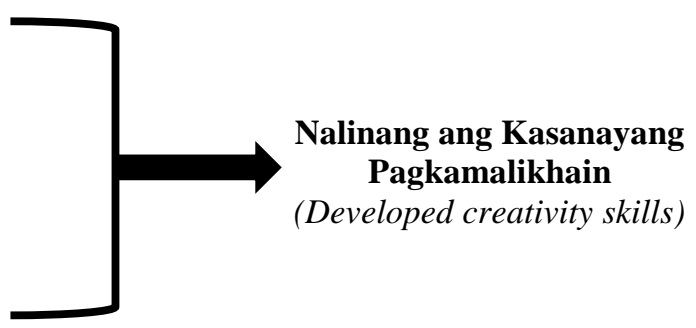


Napayaman ang analitikal na kasanayan ng mag-aaral (analytical skills of learners are enriched)

Umuunlad ang kritikal na pag-iisip kapag lumilikha ng robot (critical thinking is advanced when making a robot)

Napabuti at napagtibay ang abilidad sa pag-aanalisa (analytical ability is improved and concretized)

Napag-ibayo ang pakikitungo sa pangkatang paggawa (social skills is strengthened in performance tasks)

Napalawak ang kamalayan at kaalaman sa pangkatang gawain

(broaden knowledge through collaborative work)

Napag-iigting ang kakayahan sa pakikipagtalastasan (communicative competence is reinforced)

Napalalalim ang kaalaman kapag naibabahagi ang kayang gawing robot

(Knowledge is deepened when output is shared)

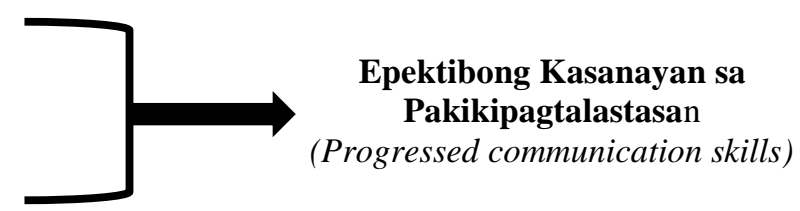

Pagpapaibayo sa mga ginagawang modelong robots (modification of model robots)

Pagpapalawig ng kaalaman sa pagtuturo ng robotics (Broadening of pedagogical strategies in robotics)

Pagkakaroon ng maraming performance-based test (inclusion of more performance-based tests)

Pagiging maliit ng grupo pagdating sa pagbuo ng robot (limited group size when making a robot)

Paglalaan ng sapat na pondo sa robotics (Allocation of sufficient funds for robotics)

Pagdaragdag ng sapat na oras sa iskedyul (More time allotment for robotics)

Pagbili ng mas makabagong kagamitan (purchase of more state-of-the-art robotics materials)

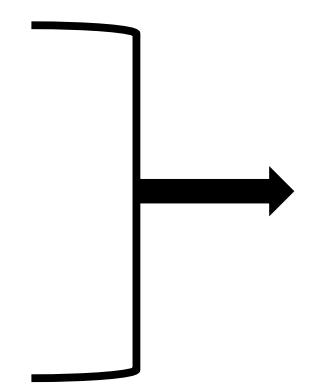

Pinagbuting kasanayan sa

kolaboratibong gawain (Improved collaborative skills) 


\section{Conclusion}

This mixed-method research that provided quantitative and qualitative information has its primary purpose to assess the gains and adherence of Robotics to the $21^{\text {st }}$ century skills of the ICTHS students. The data were drawn from survey questionnaire and openended questions. Based on the data gathered, the student-participants obtained a result of 3.37 with verbal interpretation of highly evident which indicates positive response relating to how the curriculum and instruction in Robotics expanded their knowledge. With regard to the adherence of Robotics to the 21st century skills (Critical thinking, Collaboration, Communication, Creativity and Use of Technology), a result of 3.40 with verbal interpretation of highly evident was registered. This points out that 21 st century skills have developed among students through the different activities being offered by the course. The qualitative data revealed the emergent categories as expanded ICT concepts, enhanced ICT skills, focused life-long learning skills, increased knowledge creation, developed creativity skills, enriched critical thinking skills, improved collaborative skills, progressed communication skills, human challenges and physical barriers.

The offering of Robotics in ICTHS has made significant impact on the overall concepts and skills of the students in technology, thus making them life-long learners. With the integration of robotics in the curriculum of ICTHS, the school prospectus has been made relevant and responsive to the demands of $21^{\text {st }}$ century education. However, adjustment in terms of instruction and acquisition of additional state-of-the-art robotics kits were found to be indispensable in the continuous progress of the program. This being cited, such progress may be investigated during other research opportunities whereby it will serve to be a model of mobilizing resources and tagging them along with the strategic directions set forth by the Division of City Schools.

\section{References}

ACER for Education, (2017). How Robotics Improves Education at School https://acerforeducation.acer.com/innovative-technologies/how-robotics-improveseducation-at school/\#: :text=Educational\%20robotics\%20strengthen\%20and\%20support,and $\% 20$ mechanical\%20processes\%20and\%20procedures. 
Arlegui, J., Fava, N., Menegatti, E., Monfalcon, S., Moro, M., \& Pina, A. (2008). Robotics at primary and secondary education levels: Technology, methodology, curriculum and science. In the Proceedings of the 3rd International Conference ISSEP, Toruñ, Poland.

Berkeley Center for Teaching and Learning (2017) - https://teaching.berkeley.edu/courseevaluations-question-bank

Catlin, D. (2019). Beyond Coding: Back to the Future with Education Robots//in Smart Learning with Educational Robotics - Using Robots to Scaffold Learning Outcomes. Ed. L.Daniela, Springer ISBN 978-3-030-19912-8

Churches A, (2007). Edorigami, blooms taxonomy and digital approaches http://edorigami.wikispaces.com/Bloom\%27s+and+ICT+tools

Creswell, J. W., (2009). Research Designs: Qualitative, Quantitative and Mixed Methods Approaches, 2nd Edition. University of Nebraska-Lincoln, Sage Publications

Creswell, J.W. (1998). Qualitative inquiry and research design: Choosing among five traditions, London: Sage.

Daniela, L., Lytras, M.D., (2018). Educational robotics for inclusive education//Technology, Knowledge and Learning, pp 1-7, DOI: 10.1007/s10758-018-9397-5

David F.P. (2005). Understanding and doing research: A handbook for beginners. Iloilo City: Social Science Institute, CPU

Davis, B., Sumara, D., Luce-Kapler, R. (2008). Engaging minds: Changing teaching in complex times. (2nd ed.). New York, New York: Taylor \& Francis.

Demetriou, G. A. (2011). Mobile robotics in education and research. In Z. Gacovski (Ed), Mobile Robots - Current Trends (pp.27-48). Croatia: InTech

Doerschuk, P., Bahrim, C., Daniel, J., Kruger, J., Mann, J., \& Martin, C. (2016). Closing the gaps and filling the STEM pipeline: A multidisciplinary approach. Journal of Science Education and Technology, 1-14. https://doi.org/10.1007/s10956-016-9622-8

Educational Robotics eMedia, (2018). eMedia (MEdia literacy and DIgital citizenship for All) is an Erasmus+ project (2018-1-FR01-KA201-048117) https://all-digital.org/wpcontent/uploads/2019/12/eMedia_Educational_Robotics.pdf

English, L. D. (2016). STEM education K-12: Perspectives on integration. International Journal of STEM Education, 3(1), 1-8. https://doi.org/10.1186/s40594-016-0036-1

Frankel, J.R., Wallen N.E., \& Hyun, H.H. (2012). How to design and evaluate research in education (8Th edition). New York, NY: Mc Graw Hill Companies, Inc.

García-Penalvo, F. J., Reimann, D., Tuul, M., Rees, A., \& Jormanainen, I. (2016). An overview of the most relevant literature on coding and computational thinking with emphasis on the relevant issues for teachers. In. Belgium.

Hussain, S., Lindh, J., \& Shukur, G. (2006). The effect of LEGO training on pupils' school performance in mathematics, problem solving ability and attitude: Swedish data. Educational Technology \& Society, 9(3), 182-194. Institute of museum and library services, (n.d.). 21st century skills definitions.

International Labour Organization (2016). ASEAN in transformation: How technology is changing jobs and enterprises. Geneva, ILO. http://www.ilo.org/public/english/dialogue/actemp/downloads/events/2016/singapore _2016_executive_summary.pdf

Khanlari, A. (2013). Students' perception of the effects of educational technology on their learning and characteristics. International Journal of Science and Applied Information 
International Journal of Information and Communication Technology and Education, Volume 2 Issue 1

Technology (IJSAIT), 2(2), 58-61. $\quad$ Retrieved from http://warse.org/pdfs/2018/icet4esp10.pdf

Kvale, S. (1996). InterViews-An introduction to qualitative research interviewing. Thousand Oaks, CA: Sage

Mercado, C. M. (2006). A new approach to thesis writing: Simplifying social research. Quezon City, Philippines: Development Center for Asia Africa Pacific (DCAAP).

Nugent, G., Barker, B., Grandgenett, N., \& Adamchuck, V. (2010). Impact of robotics and geospatial technology interventions on youth STEM learning and attitudes. Journal of Research on Technology in Education, 42(4), 391- 408.

Nugent, G., Barker, B., Grandgenett, N., \& Welch, G. (2016). Robotics camps, clubs, and competitions: Results from a US robotics project. Robotics and Autonomous Systems, 75, Part B, 686-691.https://doi.org/10.1016/j.robot.2015.07.011

Owen-Hill, (2016). 10 Essential Skills That All Good Roboticists Should Have https://blog.robotiq.com/10-essential-skills-that-all-good-roboticists-have

Owen-Hill, (2017). What's the Difference Between Robotics and Artificial Intelligence? https://blog.robotiq.com/whats-the-difference-between-robotics-and-artificialintelligence

Phuapan, P., Viriyavejakul, C., Pimdee, P. (2016). An Analysis of Digital Literacy Skills among Thai University Seniors. International Journal Of Emerging Technologies In Learning, 11(3), 24-31.

Rihtaršič, D., Avsec, S., \& Kocijancic, S. (2016). Experiential learning of electronics subject matter in middle school robotics courses. International Journal of Technology and Design Education, 26(2), 205-224. https://doi.org/10.1007/s10798-015-9310-7

Sullivan, F. R., \& Heffernan, J. (2016). Robotic construction kits as computational manipulatives for learning in the STEM disciplines. Journal of Research on Technology in Education, 48(2), 105128.https://doi.org/10.1080/15391523.2016.1146563

World Economic Forum (2016). The future of jobs: Employment, skills and workforce strategy for the fourth industrial revolution. Geneva, WEF. 